\title{
Implications of TTIP and TPP on Bangladesh and Nepal
}

\author{
Mohammed Nafeez Al Amin
}

Lecturer, School of Business Studies, Southeast University, Dhaka, Bangladesh

\begin{abstract}
The Transatlantic Trade and Investment Partnership (TTIP) and the Transpacific Partnership (TPP) could the biggest trade deal in the history. The EU and the USA are in the process of, or contemplating, to sign Free Trade Agreements (FTAs) under TTIP and TPP. As, the European Union (EU) and the USA are the biggest trading partner of all the South Asian countries, such preferential tariff arrangements could lead to significant erosion of preferences enjoyed currently by the South Asian Developing Countries such as, Bangladesh and Nepal. In this backdrop, the main objective of the present study is to investigate the potential economic impacts of tariff eliminations under TPP and TTIP on various macro and trade variables of Bangladesh and Nepal. In this context, a standard computable general equilibrium (CGE) analysis has been adopted by using the Global Trade Analysis Project (GTAP) model and database to explore the aggregate impact as well as sectoral implications. The analysis evinces that complete integration in terms of tariff elimination under these two mega deals, Bangladesh and Nepal could face tremendous negative impact on their economy. The analysis also suggests that Bangladesh and Nepal may consider joining to the TPP to minimize the negative economic impact due to the mentioned deals.
\end{abstract}

Keywords: TPP, TTIP, Bangladesh, Nepal, GTAP, CGE JEL Classification Code: F14, F15, F17

\section{INTRODUCTION AND RATIONAL OF THE STUDY}

The Trans-Pacific Partnership (TPP) negotiations are already taking place involving the U.S. and 11 other countries, which account for about 40 percent of the global economy. The TPP is a proposed trade agreement under negotiation by (as of August 2013) Australia, Brunei, Chile, Canada, Japan, Malaysia, Mexico, New Zealand, Peru, Singapore, the United States, and Vietnam ${ }^{1}$. The TPP intends to enhance trade and investments among the TPP partner countries, promote innovation, economic growth and development, and support the creation and retention of jobs ${ }^{2}$.

Recently, the U.S. and the EU reaffirmed their commitment to conclude expeditiously a comprehensive and ambitious Transatlantic Trade and Investment Partnership (TTIP) that already accounts for nearly half of global output (EU 2014). On 13 February 2013, the President of the United States, the President of the European Commission and the President of the European Council made a joint announcement to be effect that the EU and the USA have agreed to launch negotiations on the TTIP with the aim of signing an agreement in $2015^{3}$. The key issues that are considered here relate to identification of the most important products in the US or the EU imports from South Asia

${ }^{1}$ Michael, Gabriel (18 November 2013). "The United States is isolated in the Trans-Pacific Partnership negotiations". The Monkey Cage. washingtonpost.com. Retrieved 10 April 2014

2 "The US and the TPP". USTR. Retrieved 10 April 2014

${ }^{3}$ European Commission (2013) (MEMO/13/95) “European Union and United States to Launch Negotiations for a Transatlantic Trade and Investment Partnership" and how vulnerable the products are to trade diversion/preference erosion. As far as tariffs are concerned, the European Union and the USA currently apply most favored nation (MFN) tariffs in trading with one another. These MFN tariffs will be abolished if this transatlantic trade deal is signed. The size of losses in terms of competitiveness of the excluded countries will depend on the degree to which such tariff elimination will impact on their relative competitive strength of these excluded South Asian countries.

There are numerous studies using Computable General Equilibrium (CGE) modelling, like Lee and Itakura (2014), Cheong (2013), Rahman and Cheong (2014) Arif et.al (2014), Xin (2014), Narayanan and Sachin (2014) and Petri et.al (2011). These studies were seen to be quantifying the impact of TPP and TTIP on different regions. Cheong (2013) analyzed the progress on major issues regarding the current TPP negotiations which are being led by the United States, and draws implications for East Asian economic integration. The impact of forming the TPP under three scenarios was estimated using the GDyn, a recursive dynamic computable general equilibrium (CGE) model developed by the Global Trade Analysis Project (GTAP). The three scenarios are TPP9 (nine TPP members), TPP12 (12 members), and TPP12+ China (13 members). The paper argues that the TPP should be promoted for its economic value, not for geopolitical purposes and it should be open to all Asia and Pacific countries, including the People's Republic of China.

Narayanan and Sachin (2014) conducted a comparative analysis of the likely impact of tariff reduction under 
TPP of Indian economy under different scenarios, by using the standard GTAP model and suggested that there are mixed prospects and no strong reason for India to pursue being part of the TPP.

Arif et.al (2014), examine the impacts of TPP on Turkish economy. By using Global Trade Analysis Project (GTAP) database and a general equilibrium model, the effects of various scenarios on GDP and exports were studied. Obtained results show that Turkey could face losses on GDP up to $1 \%$ if the TPP covers only current twelve countries.

Petri et.al (2011) did a quantitative assessment of the Trans-Pacific Partnership and Asia-Pacific integration by using GTAP database. According to this study, TPP and an Asian Track could consolidate the "noodle bowl" of current smaller agreements and provide pathways to a Free Trade Area of the Asia-Pacific (FTAAP). The effects on the world economy would be small initially, but by 2025 the annual welfare gain would rise to $\$ 104$ billion on the TPP track, $\$ 303$ billion on both tracks and $\$ 862$ billion with an FTAAP. The study also mentioned that strong economic incentives would emerge for the USA and China to consolidate the tracks into a region-wide agreement.

Akhtar and Vivian (2014) concluded their paper and where they envisioned that the TTIP could be the largest FTA in the world in terms of economic size and serve a number of strategic U.S. policy goals. Ham (2013) has explored the logic of TTIP from a geopolitical point of view and global normative convergence. He has shown that the TTIP may have a rather unpredictable impact on the future of the EU. Jim Rollo et.al (2014) evaluate some of the potential effects of EU-US TTIP economic integration on the trade in goods of 43 low-income countries and show that most of the low income countries will suffer negative impact due to the mega deal.

The above brief review shows that various aspects of TPP and its impact on different regions have been analyzed. However, not much research has been done to quantify the impact of TPP and TTIP on the economy of Bangladesh and Nepal. It would be interesting to see the impact of TPP and TTIP on the economies of the above mentioned countries. If these two sets of trade talks are successfully concluded, Bangladesh and Nepal may find itself put in a disadvantageous position. The US and the EU is the major trading partner of South Asian Countries including India, Bangladesh, Pakistan, Sri Lanka and Nepal (table 2). Indian Exports to the EU and the USA was US\$ 49 billion and US\$ 42 billion while import from the EU and the USA was US\$ 48 billion and US\$ 23billion respectively in 2013 (UNCOMTRADE 2014). Bangladesh's exports to the EU and the USA were US\$ 14 billion and US\$ 5 billion respectively which is 80 percent of countries total exports in 2013. The other South Asian countries show similar trends as well.

\section{OBJectives OF The Study}

With the explanations from the above background, the objective of this study is to make a comparative analysis of likely impact of tariff reduction under TPP and TTIP on various macro and trade variables of Bangladesh and Nepal's economy by using GTAP model. Bangladesh being one of the top 5 growing economies of the world receives a lot of attention and on the other hand Nepal is a growing economy which gets benefitted from being a SAARC nation and also by having China and India as its neighbours. Thus, these two countries were selected.

The unique contribution of this paper lies in the evaluation of scenarios wherein South Asian countries such as, Bangladesh and Nepal may be involved in the TPP as alternative. This has the potential to provide deep insights to the currently active policy debate on TPP and TTIP for Bangladesh and Nepal.

\section{MetHodology}

Before moving into the GTAP methodology, we have a look at the total bilateral trade flows between the regions involved in this paper (see table 1 and table 2 for details). The top sources of South Asian's imports are EU27, Japan, USA, Canada and Australia, of which the last four are current TPP members. All major South Asian's top export destinations include EU27, USA, Japan and Korea. Therefore, South Asian is closely related to the proposed TPP members and it is important to consider their involvement in this partnership.

Simple average tariff of the EU against the USA is 4.1 percent and the average US MFN tariff against the EU is 3.5 percent (Europa 2014). These are not high average tariffs and as such do not suggest a Free Trade Agreement (FTA) would endow major competitive advantage to either the EU or the USA through transatlantic trade. While the average tariff between the USA and EU stands 3-4 percent, nontariff barriers are extremely high, ranging from 25.5 $\sim 73$.3percent ${ }^{4}$. Therefore, elimination of non-tariff barriers may actually cause more damage to South Asia than elimination of tariffs.

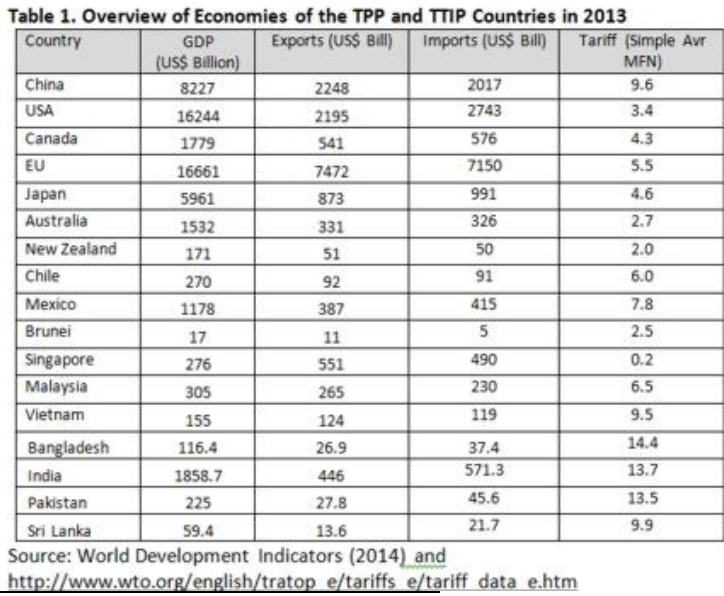

4 ECORYS (2009), Non-Tariff Measures in EU-US Trade and Investment-An Economic Analysis. p .xix, xx 


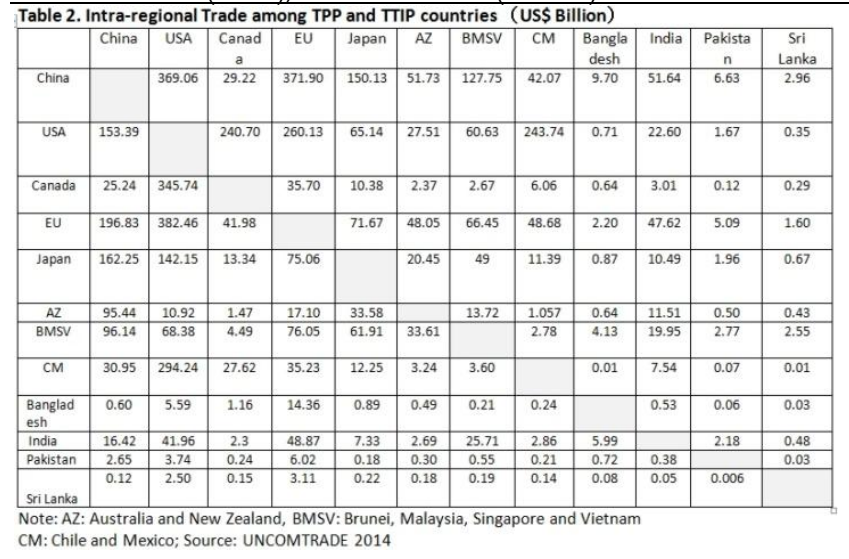

THE GTAP MODEL FOR MACROECONOMIC ANALYSIS ${ }^{5}$

The most common modeling technique for estimating economic impacts of a trade agreement with economywide effects involves the computable general equilibrium (CGE) modeling framework of the Global Trade Analysis Project (GTAP). The general equilibrium model is thoroughly documented in Hertel (1997) and in the GTAP database documentation (Dimaranan, 2006). It is a comparative static multi-regional CGE model.

The basic structure of the GTAP database includes: industrial sectors, households, governments, and global sectors across countries. Countries and regions in the world economy are linked together through trade. Prices and quantities are simultaneously determined in both factor markets and commodity markets. The main factors of production are skilled and unskilled labor, capital, natural resources and land.

Producers operate under constant returns to scale, where the technology is described by the Leontief and CES functions. Two broad categories of inputs are identified: intermediate inputs and primary factors of productions. In the model, firms minimize costs of inputs given their level of output and fixed technology. First, producers use composite units of intermediate inputs and primary factors in fixed proportions following a Leontief production function. At the second level of the production nest, intermediate input composites are obtained combining imported bundles and domestic goods of the same input-output group. Trade policy can affect the price of traded goods relative to domestically produced goods. As a result, a key relationship for model analysis is the degree of substitution between imported and domestic goods. This key relationship is commonly identified as the Armington elasticity ${ }^{6}$. It is assumed that domestically produced goods and imports are imperfectly substituted. This is modeled using the Armington structure.

\footnotetext{
${ }^{5}$ Hertel, T.W. (1997), Global Trade Analysis: Modeling and Applications and the GTAP website at https://www.gtap.agecon.purdue.edu for a full introduction to the database.

${ }^{6}$ The constant elasticity of substitution (CES) specification for the trade substitution elasticity is derived from Armington (1969).
}

Households' behavior in the model is determined from an aggregate utility function. The aggregate utility is modeled using a Cobb-Douglas production function with constant expenditure shares. This utility function includes private consumption, government consumption and savings. Current government expenditure goes into the regional household utility function as a proxy for government provision of public goods and services. Private households' consumption is explained by a constant difference elasticity expenditure function.

Domestic support and trade policy (tariff barriers) are modeled as ad valorem equivalents. These policies have a direct impact on the production and consumption sectors in the model. In equilibrium, all firms have zero real profit, all households are on their budget constraint, and global investment is equal to global savings. Changing the model's parameters allows one to estimate the impact from a country's/region's original equilibrium position to a new equilibrium position.

The simulation represents what the economy would look like if the policy change or shock had occurred. The difference in the values of the endogenous variables in the baseline and the simulation represents the effect of the policy change. All the policy simulations as well as results reported in the paper, as in other major models of this type, may be thought of as occurring in one-shot over a time-period that is needed for equilibrium to be achieved. This time-period is akin to what is widely thought of by economists as 'medium run', possibly 3-5 years in a go. So the model should be able to foretell the effect on trade and production patterns if the trade policy was changed. Furthermore, based on the change in welfare, the policy-maker would be able to judge whether the country benefited from the change in policy or not.

The GTAP framework has strength because of theoretical rigor, its ability to represent direct and indirect interactions among all sectors of an economy and precise detailed quantitative results. The strength of the multicountry CGE model is that incorporates in an elegant manner, the features of neo-classical general equilibrium and real international trade models in an empirical framework (Thierfelder, et al., 2007). However, this study does not adequately capture the service trade reforms and thus the result may underestimate the potential effect of liberalization where services sector is to be included. It is to be noted that GTAP model has both static and dynamic versions. However, in this paper, static GTAP model is used. Gilbert (2013) mentioned that the static model has disadvantages relative to dynamic techniques, of not describing the time path, i.e. attention in the analysis is concentrated on the end outcome rather than the transition. The model's results may be very sensitive to the assumptions and data used. Almost all CGE exercises include a sensitivity analysis to obtain a range of results based on different assumptions or data. 


\section{Data AND Country and Sectoral Aggregation}

The study makes use of Version 8 of the GTAP database which has been released in 2012. Data on regions and commodities are also aggregated to meet the objectives of this study. Version 8 of the GTAP database covers 57 commodities, 129 regions/countries and 5 factors of production. For the sake of convenience the 129 regions have been aggregated to 17 regions and the 57 commodities have been aggregated into 10 as shown in Annex 1. The regions selected include major nine TPP countries (Australia and New Zealand as one country), the EU, five South Asia countries, China, Sub Saha Africa (SSA) and Rest of the World. The study has simulated three different scenarios including on EU-USA FTA, TPP free trade agreement and a alternative scenario where if Bangladesh and Nepal joins the TPP.

\section{ANALYSIS OF Simulation Results: Welfare AND MACROECONOMIC EFFECT}

Based on the model simulations, this section reports the results that show the likely impacts on important macroeconomic variables, economic welfare, industry outputs and exports. We have analyzed four different scenarios. Under Scenario I, elimination of all import tariffs by the EU and the USA and their vice versa, under Scenario II, all 12 TPP countries eliminates tariff for each other. We have also adopted one alternative scenario if South Asian countries which include Bangladesh and Nepal join the TPP.

\begin{tabular}{|c|c|c|c|c|c|}
\hline Country & $\begin{array}{l}\text { Welfare Effect } \\
\text { (US\$ million) }\end{array}$ & $\begin{array}{l}\text { \% Change of } \\
\text { Real GDP }\end{array}$ & ToT & $\begin{array}{l}\text { \% Change } \\
\text { of Exports }\end{array}$ & $\begin{array}{l}\text { \% Change of } \\
\text { Imports }\end{array}$ \\
\hline China & -2115.31 & -0.19 & -0.15 & -0.12 & -0.29 \\
\hline USA & 100.88 & -0.05 & 0.01 & 0.48 & 0.28 \\
\hline EU27 & -1575 & -0.09 & -0.02 & 0.04 & -0.05 \\
\hline Canada & 219.58 & -0.06 & -0.02 & 0.13 & 0.13 \\
\hline Mexico & 318.32 & -0.12 & -0.14 & 0.38 & 0.36 \\
\hline Aust Newz & 1177.03 & 0.76 & 0.56 & 0.42 & 1.31 \\
\hline Japan & 5966.24 & 0.51 & 0.43 & 0.77 & 1.81 \\
\hline Singapore & 186.05 & 0.2 & 0.09 & 0.15 & 0.27 \\
\hline Malaysia & 1126.81 & 0.41 & 0.09 & 1.21 & 2.46 \\
\hline Viet Nam & 2201.71 & 4.74 & 1.4 & 4.41 & 7.82 \\
\hline Bangladesh & -41.46 & -0.29 & -0.19 & -0.10 & -0.37 \\
\hline India & -348.47 & -0.14 & -0.09 & 0.02 & -0.14 \\
\hline Pakistan & -83.88 & -0.26 & -0.18 & 0.07 & -0.28 \\
\hline Sri Lanka & -32.05 & -0.33 & -0.22 & 0.11 & -0.3 \\
\hline Nepal & -3.25 & -0.18 & -0.08 & 0.09 & -0.12 \\
\hline SSA & -76.84 & -0.09 & -0.01 & 0 & -0.09 \\
\hline Rest of World & -2426.32 & -0.11 & -0.05 & -0.02 & -0.15 \\
\hline
\end{tabular}

The effects of TPP can be assessed at both the macroeconomic and sectoral levels of analysis. The welfare and other macroeconomic effects of the simulations for the countries/regions concerned are presented in Table 3.

Under Scenario I, if the TTP countries completely eliminate import tariffs each other, all South Asian countries are expected to drop their exports and the welfare loss. As India is the biggest economy of South Asia, it's real GDP and welfare loss will be higher than any other countries in the region. Bangladesh could also face tremendous pressure in terms of export and welfare. In terms of real GDP, Bangladesh may be the biggest sufferer amongst the South Asian countries. This mega
TPP FTA deal could tremendously have a negative impact in the South Asian economy and this could be much higher compared to TTIP. Bangladesh's exports are expected to drop by about 0.10 percent and the welfare loss equals US \$ 41 million. Bangladesh would experience a fall in real GDP by 0.29 percent if the deal becomes realized. The terms of trade (ToT) would fall by 0.19 percent as well.

Nepal would experience a fall in real GDP by 0.18 percent and a fall in Imports by 0.12 . However a positive change in Exports (0.09 percent) may be resulted if the TPP FTA deal is established. The welfare and terms of trade is also likely to have a negative impact, but the extent of those not as significant as the impact on Bangladesh.

However, the world second biggest economy China could face in the very disadvantage position due to this mega deal. Chinese exports are expected to drop by about 0.12 percent and the welfare loss equals US \$ 2.1 billion. However, the biggest welfare gains from this mega FTA could be by Japan followed by the USA and Vietnam. The EU may loss their welfare and real GDP significantly.

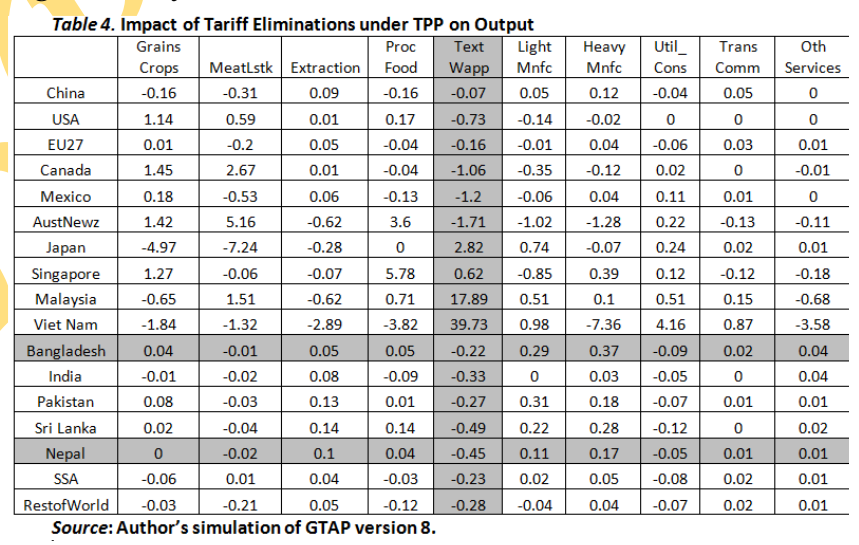

The table 4 shows the sectotal analysis under TPP. It shows that under TPP, Bangladesh and Nepal's Textiles and Clothing will suffer tremendously and production may fall significantly. Nepal could be affected negatively the most in the South Asian region.

Table 5. Economic Impact of Tariff Eliminations under TTIP (Scenario II)
\begin{tabular}{|l|r|r|r|r|r|}
\hline Country & $\begin{array}{c}\text { Welfare } \\
\text { Effect (US\$ } \\
\text { million) }\end{array}$ & $\begin{array}{c}\text { \% Change of } \\
\text { Real GDP }\end{array}$ & Tot & $\begin{array}{c}\text { \% Change } \\
\text { of Exports }\end{array}$ & $\begin{array}{c}\text { \% Change } \\
\text { of Imports }\end{array}$ \\
\hline China & -1157.06 & -0.14 & -0.04 & -0.01 & -0.1 \\
\hline USA & 6051.83 & 0.23 & 0.26 & 1 & 1.07 \\
\hline EU27 & 1051.82 & -0.05 & 0 & 0.17 & 0.16 \\
\hline Canada & -793.99 & -0.18 & -0.16 & -0.04 & -0.34 \\
\hline Mexico & -439.22 & -0.18 & -0.16 & -0.01 & -0.34 \\
\hline AustNewz & -149.96 & -0.11 & -0.04 & 0.05 & -0.11 \\
\hline Japan & -587.33 & -0.13 & -0.06 & 0.12 & -0.13 \\
\hline Singapore & -73.62 & -0.1 & -0.02 & -0.03 & -0.09 \\
\hline Malaysia & -68.54 & -0.12 & -0.03 & -0.02 & -0.09 \\
\hline VietNam & -45.78 & -0.19 & -0.04 & -0.04 & -0.12 \\
\hline Bangladesh & -19.82 & -0.2 & -0.08 & -0.02 & -0.17 \\
\hline India & -220.39 & -0.11 & -0.03 & 0.01 & -0.09 \\
\hline Pakistan & -32.37 & -0.17 & -0.08 & 0.04 & -0.14 \\
\hline Srilanka & -12.16 & -0.21 & -0.08 & 0.08 & -0.13 \\
\hline Nepal & -1.42 & -0.14 & -0.04 & 0.08 & -0.08 \\
\hline SSA & -157.23 & -0.12 & -0.03 & 0.02 & -0.11 \\
\hline RestofWorld & -2240.17 & -0.12 & -0.04 & 0 & -0.1 \\
\hline
\end{tabular}


Under Scenario II (table 5), if the EU and the USA completely eliminates import tariffs each other, South Asian countries would experience a fall in real GDP and loss welfare but not very significantly compared to TPP. This is also true in the case of Bangladesh and Nepal. This mega FTA deal could affect negatively almost all part of the world. However, the biggest welfare gain by the USA which could be about US \$ 6.1 billion and the EU would also gain welfare significantly. Chinese exports are expected to drop by about 0.01 percent and the welfare loss equals US $\$ 1.2$ billion.

The table 6 shows that under TTIP South Asian Textiles and Clothing industry may face some difficulties particularly Nepal. Impact on Bangladesh will not be as significant as it showed for TTP. The Agriculture sector may not face any significant difficulties in South Asian countries except India.

\begin{tabular}{|c|c|c|c|c|c|c|c|c|c|c|}
\hline & $\begin{array}{l}\text { Grains } \\
\text { Crops }\end{array}$ & Meatlstk & Extraction & $\begin{array}{l}\text { Proc } \\
\text { Food }\end{array}$ & $\begin{array}{l}\text { Text } \\
\text { Wapp } \\
\end{array}$ & $\begin{array}{l}\text { Light } \\
\text { Mnfc }\end{array}$ & $\begin{array}{l}\text { Heavy } \\
\text { Mnfc }\end{array}$ & $\begin{array}{l}\text { Util_ } \\
\text { Cons }\end{array}$ & $\begin{array}{l}\text { Trans } \\
\text { Comm }\end{array}$ & $\begin{array}{l}\text { Oth } \\
\text { Services }\end{array}$ \\
\hline China & 0.01 & 0 & 0.02 & -0.02 & -0.08 & 0.01 & 0.01 & -0.04 & 0.01 & 0 \\
\hline USA & 0.06 & 0.24 & -0.14 & 0.12 & -0.42 & 0.17 & -0.04 & 0.1 & -0.01 & -0.02 \\
\hline EU27 & -0.14 & -0.19 & -0.04 & 0.03 & 0.69 & -0.07 & 0.03 & 0.01 & 0.02 & 0.01 \\
\hline Canada & 0.17 & 0.18 & 0.04 & -0.18 & -0.3 & 0.05 & -0.02 & -0.15 & 0 & 0.02 \\
\hline Mexico & 0.11 & 0.07 & 0.06 & -0.08 & -0.54 & 0.15 & 0.06 & -0.19 & 0 & 0.01 \\
\hline AustNewz & 0.02 & 0.03 & 0 & -0.06 & -0.03 & 0.01 & 0.03 & -0.06 & 0 & 0.01 \\
\hline Japan & 0.07 & 0.03 & 0.02 & -0.01 & -0.02 & 0.04 & 0.04 & -0.09 & 0 & 0 \\
\hline Singapore & 0.01 & -0.03 & -0.01 & -0.1 & -0.34 & -0.04 & -0.1 & -0.1 & 0.04 & 0.06 \\
\hline Malaysia & 0 & -0.02 & 0.01 & -0.05 & -0.33 & 0.01 & -0.04 & -0.02 & 0.01 & 0.05 \\
\hline VietNam & 0.03 & 0.01 & 0.04 & -0.1 & -0.64 & -0.01 & 0.11 & -0.07 & 0.01 & 0.1 \\
\hline Bangladesh & 0.01 & 0 & 0.01 & -0.02 & -0.06 & 0.06 & 0.14 & -0.07 & 0.01 & 0.04 \\
\hline India & -0.01 & 0 & 0 & -0.02 & -0.18 & -0.01 & -0.02 & -0.04 & -0.01 & 0.04 \\
\hline Pakistan & 0.02 & -0.01 & 0.04 & 0.01 & -0.14 & 0.09 & 0.07 & -0.04 & 0.01 & 0.03 \\
\hline Srilanka & 0.04 & -0.03 & 0.05 & 0.05 & -0.26 & 0.07 & 0.1 & -0.08 & 0 & 0.03 \\
\hline Nepal & 0 & -0.01 & 0.01 & 0.01 & -0.22 & 0.02 & 0.03 & -0.06 & 0.01 & 0.02 \\
\hline SSA & -0.01 & -0.01 & 0.01 & -0.02 & -0.09 & -0.01 & 0.01 & -0.1 & 0.01 & 0.02 \\
\hline RestofWorld & 0.01 & -0.01 & 0.01 & -0.04 & -0.18 & -0.01 & -0.01 & -0.06 & 0.01 & 0.02 \\
\hline
\end{tabular}

The table 7 shows the economic impact of TTP if South Asian countries able to join TPP (under scenario III). It shows that South Asian countries could gain significantly in terms of welfare, real GDP as well as exports. Bangladesh and Nepal would experience a rise in real GDP by 2.39 percent and 5.1 percent respectively. This mega FTA deal may have a positive effect on the South Asian Countries. This indicates that Bangladesh and Nepal should try to enter into the TPP deal.

\begin{tabular}{l} 
Table 7. Economic Impact of Tariff Eliminations under TPP including SA (Scenario III) \\
\begin{tabular}{|c|c|c|c|c|c|}
\hline Country & $\begin{array}{c}\text { Welfare } \\
\text { Effect (US\$ } \\
\text { million) }\end{array}$ & $\begin{array}{c}\text { \% Change of } \\
\text { Real GDP }\end{array}$ & ToT & $\begin{array}{c}\text { \% Change } \\
\text { of Exports }\end{array}$ & $\begin{array}{c}\% \text { Change of } \\
\text { Imports }\end{array}$ \\
\hline China & -3936.98 & -0.37 & -0.23 & -0.22 & -0.5 \\
\hline USA & 1913.24 & -0.03 & 0.07 & 0.79 & 0.52 \\
\hline EU27 & -2548.74 & -0.17 & -0.03 & 0.04 & -0.1 \\
\hline Canada & 359.7 & -0.02 & 0.02 & 0.2 & 0.23 \\
\hline Mexico & 479.52 & -0.16 & -0.16 & 0.42 & 0.32 \\
\hline AustNewz & 2343.82 & 1.15 & 1.02 & 0.85 & 2.24 \\
\hline Japan & 7104.12 & 0.63 & 0.58 & 0.89 & 2.1 \\
\hline Singapore & 815.97 & 0.82 & 0.4 & 0.46 & 0.96 \\
\hline Malaysia & 1857.25 & 0.94 & 0.43 & 1.43 & 3.04 \\
\hline Viet Nam & 2184.27 & 4.63 & 1.38 & 4.52 & 7.94 \\
\hline Bangladesh & 428.61 & 2.39 & 1.51 & 7.37 & 8.88 \\
\hline India & 4672.5 & 0.39 & 0.1 & 4.25 & 4.07 \\
\hline Pakistan & 1019.99 & 2.03 & 1.53 & 5.62 & 6.21 \\
\hline Sri Lanka & 317.39 & 2.34 & 1.85 & 2.79 & 7.29 \\
\hline Nepal & 211.16 & 5.01 & 2.79 & 17.75 & 14.31 \\
\hline SSA & -624.88 & -0.31 & -0.16 & 0.02 & -0.32 \\
\hline RestofWorld & -6379.23 & -0.26 & -0.15 & -0.05 & -0.33 \\
\hline
\end{tabular} \\
Source: Author's simulation of GTAP version 8. \\
\hline
\end{tabular}

However, the sectoral analysis (table 8) shows the mixed pictures. The main textiles and clothing sector could increase output in Bangladesh and Nepal tremendously, but the agricultural and industrial sector may reduce production whether they join TPP or not. Adverse effects on agricultural sectors could be more negative if nontariff measures are taken into consideration.

\begin{tabular}{|c|c|c|c|c|c|c|c|c|c|c|}
\hline & $\begin{array}{l}\text { Grains } \\
\text { Crops }\end{array}$ & Meatlstk & Extraction & $\begin{array}{l}\text { Proc } \\
\text { Food }\end{array}$ & $\begin{array}{l}\text { Text } \\
\text { Wapp }\end{array}$ & $\begin{array}{l}\text { Light } \\
\text { Mnfc }\end{array}$ & $\begin{array}{l}\text { Heavy } \\
\text { Mnfc }\end{array}$ & $\begin{array}{l}\text { Util__ } \\
\text { Cons }\end{array}$ & $\begin{array}{l}\text { Trans } \\
\text { Comm }\end{array}$ & $\begin{array}{l}\text { Oth } \\
\text { Services }\end{array}$ \\
\hline China & -0.16 & -0.29 & 0.1 & -0.14 & -0.46 & 0.13 & 0.15 & -0.09 & 0.09 & -0.02 \\
\hline USA & 1.26 & 0.68 & -0.08 & 0.21 & -2.33 & -0.09 & 0.06 & 0 & 0 & 0 \\
\hline EU27 & 0.04 & -0.18 & -0.13 & -0.03 & -0.13 & -0.03 & -0.01 & -0.11 & 0.07 & 0.02 \\
\hline Canada & 4.38 & 2.85 & -0.11 & -0.09 & -3.54 & -0.42 & -0.06 & 0.03 & 0 & -0.02 \\
\hline Mexico & 0.25 & -0.37 & 0.13 & -0.09 & -3.6 & 0.02 & 0.05 & 0.06 & 0.02 & 0.02 \\
\hline AustNewz & 1.68 & 3.58 & -0.07 & 2.7 & -2.68 & -1.41 & -0.64 & 0.34 & -0.16 & -0.1 \\
\hline Japan & -5.01 & -7.31 & -0.39 & -0.11 & 2.51 & 0.87 & -0.13 & 0.25 & 0.02 & 0.02 \\
\hline Singapore & 1.76 & -0.3 & -0.11 & 22.42 & 2.41 & -0.14 & 0.96 & 0.48 & -0.47 & -0.57 \\
\hline Malaysia & -0.02 & 1.55 & -0.11 & 4.18 & 17.97 & 0.58 & -0.52 & 0.43 & 0.03 & -0.72 \\
\hline VietNam & -1.69 & -2.26 & -2.84 & -3.86 & 38.08 & 1.18 & -6.97 & 4.24 & 0.88 & -3.65 \\
\hline Bangladesh & -0.6 & -0.41 & -1.04 & \begin{tabular}{|l|}
-2.49 \\
\end{tabular} & 6.59 & -6.67 & -7.51 & 0.92 & -0.48 & -0.76 \\
\hline India & -0.22 & 0.09 & -0.99 & -0.22 & 6.11 & -0.79 & -0.39 & 0.65 & 0.25 & -0.34 \\
\hline Pakistan & -0.38 & 0.17 & -1.73 & -2.47 & 7.52 & -11.84 & -3.46 & 0.78 & -0.16 & -0.07 \\
\hline Srilanka & -2.01 & 0.34 & -1.72 & -4.45 & 13.05 & -1.39 & -5.92 & 2.66 & 0.39 & -0.79 \\
\hline Nepal & -0.06 & 1.12 & -2.81 & \begin{tabular}{|l|l|}
6.83 \\
\end{tabular} & 2.24 & -15.91 & 12.9 & 3.11 & -0.73 & -0.37 \\
\hline SSA & -0.07 & 0 & -0.03 & 0.03 & -0.3 & 0.18 & 0.08 & -0.2 & 0.07 & 0.02 \\
\hline RestofWorld & -0.02 & -0.18 & -0.02 & -0.14 & -0.8 & -0.01 & 0.1 & -0.12 & 0.06 & 0.03 \\
\hline
\end{tabular}

\section{Conclusion}

The Transatlantic Trade and Investment Partnership (TTIP) and the Transpacific Partnership (TPP) could be two of the biggest trade deals in the history which account for about 60 percent of the global economy. The EU and the USA is in the process of, or contemplating, to sign Free Trade Agreements (FTAs) under TTIP and TPP. The European Union (EU) and the USA is the biggest trading partner of all South Asian countries. Therefore, the TTIP and TPP are immensely important for both Bangladesh and Nepal. In this backdrop, the main objective of the present study is to investigate the potential economic impacts of tariff reduction under TPP and TTIP on various macro and trade variables of South Asian Economies under different scenarios using the Global Trade Analysis Project (GTAP) model and database to explore the aggregate impact as well as sectoral implications. This study used GTAP model of 17 aggregated regions and 10 aggregated tradable commodities to understand the potential impact of TTIP and TPP on South Asia. Under Scenario I, all TPP countries eliminates import tariff for each other and under Scenario II, elimination of all import tariffs by the EU and the USA to each other. We have also adopted an alternative scenario to investigate the economic implications if Bangladesh and Nepal joins the TPP under scenario III.

The analysis evince that under completely integration in terms of tariff elimination under TTIP and TPP, the real GDP of South Asian countries like Bangladesh and Nepal could decrease by 0.49 percent and 0.32 percent respectively. Bangladesh's exports may fall about 0.12 percent as well. However, Nepal's exports may not fall as expected. The agricultural and textiles and clothing industry may suffer tremendously and production may fall significantly for the two countries. However, if Bangladesh and Nepal could enter the TPP deal, the economic gain could be enormous. This indicates that these two South Asian countries could gain significantly in terms of welfare, real GDP as well as exports. Bangladesh and Nepal would experience a rise in real GDP by 2.39 percent and 5.1 
Asian Business Review, Volume 5, Number 1/2015 (Issue 10)

ISSN 2304-2613 (Print); ISSN 2305-8730 (Online)

percent respectively. This suggests that Bangladesh and

Nepal should try to enter into the TPP deal.

\section{REFERENCES}

Alam, M., \& Islam, M. (2012). Plan and Policies for Success in the Business World: A Conceptual Study. ABC Journal Of Advanced Research, 1(1), 60-69. Retrieved from http://journals.abc.us.org/index.php/abcjar/article/view/24

Appendixes, Akhtar S.I and Vivian C.J (2014) "Transatlantic Trade and Investment Partnership (TTIP) Negotiations" Congressional Research Service, USA

Arif Oduncu and Merve Mavus and Didem Gunes (2014), “The Possible Effects of Trans-Pacific Partnership on Turkish Economy", MPRA Paper No. 52917, posted 14. January 2014 08:01 UTC http:/ / mpra.ub.uni-muenchen.de/52917/

Armington, Paul S. (1969) “A Theory of Demand for Products Distinguished by Place of Production" IMF Staff Papers, V.16, no.1, pp. 159-176

Asfaw, H. (2015). Trade Policy and Economic Growth in Sub-Saharan Africa: A Panel Data Approach. American Journal Of Trade And Policy, 2(1), 7-14. $\quad$ Retrieved from http://journals.abc.us.org/index.php/ajtp/article/view/4.1.15

Chile, L., \& Talukder, D. (2014). The Paradox of Agricultural Trade Liberalization in Bangladesh and Tanzania. American Journal Of Trade And Policy, 1(1), 23-31. Retrieved from http://journals.abc.us.org/index.php/ajtp/article/view/1.3

Gasiorek M. et al. (2010) Mid-term Evaluation of the EU's Generalised System of Preferences, Centre for Analysis for Regional Integration at Sussex, University of Sussex.

Gilbert, John (2013), “The Economic impact of new regional trading developments in the ESCAP region" Asia Pacific Development Journal, Vol.20, no. 1

Ham Peter V. (2013) "The Geopolitics of TTIP", Clingendael Policy Brief No. 23 Netherlands http://www.clingendael.nl/sites/default/files/The\%20G eopolitics $\% 20$ of $\% 20$ TTIP $\% 20$ -

\%20Clingendael\%20Policy\%20Brief.pdf accessed on 27 June,2014

Hertel, T.W. (ed.) (1997), “Global Trade Analysis: Modeling and Applications", Cambridge and New York: Cambridge University Press.

http:/ / transatlantic.sais-

jhu.edu/publications/CRS_TTIP_report_Feb_2014.pdf, accessed on 27 June 2014

Inkyo Cheong (2013), “Negotiations for the Trans-Pacific Partnership Agreement: Evaluation and Implications for East Asian Regionalism", ADBI Working Paper Series, Working no. 428, Asian Development Bank Institute.

Jim Rollo et.al (2014):" Potential Effects of the Proposed Transatlantic Trade and Investment Partnership on Selected Developing Countries", CARIS, University of Sussex, Brighton, UK http:/ / tradesift.com/Reports/Potential\%20Effects\%20of\% 20the \%20Proposed \%20Transatlantic\%20Trade\%20and \% 20I nvestment \%20Partnership \%20on\%20Selected\%20Developi ng\%20Countries_DFID_Final\%20Report_July2013.pdf, accessed on 27 June 2014

Kimura Fukunari, (2006) "International Production and
Distribution Networks in East Asia: Eighteen Facts, Mechanics, and Policy Implications", Asian Economic Policy Review, vol. 1, Issue 2, pp 326-344, December

Lee Hiro and Ken Itakura (2014), “TPP, RCEP and Japan's Agricultural Policy Reforms", OSIPP Discussion Paper: DP-2014-E-003.

Mikic, Mia (2009), ASEAN and Trade Integration, Staff Working paper 01/09, TID, ESCAP (http://www.unescap.org/tid/publication/swp109.pdf)

Narayanan. Badri and Sachin Kumar Sharma (2014) An analysis of Trans-Pacific Atlantic Partnership (TPP): Implications for Indian Economy, Centre for WTO Studies, Indian Institute of Foreign Trade, New Delhi, India

Oluwatosin .O., O., Daisi, O., \& Oluwashikemi, R. (2013). Economic Globalization, Income Inequality and Economic Growth in Nigeria: A Static Data Analysis (1986-2010). ABC Journal Of Advanced Research, 2(2), 55-68. Retrieved from http://journals.abc.us.org/index.php/abcjar/article/view/4.5

Petri, Peter A. ,Michael G. Plummer, and Fan Zhai (2011), “The Trans-pacific partnership and Asia-pacific integration: A quantitative Assessment", Economic series no. 119, EastWest centre working papers, October 24

Rahman M.M and Cheong I. (2014) "New Trade Policy of EU: Implication for LDCs", Journal of International Trade and Logistics, Vol 12. No. 1. Incheon, Korea

Winters, L Alan, et.al (2009) "Innocent Bystanders: Implications of an EU-India free trade agreement for excluded countries", Commonwealth Secretariat, United Kingdom

Xin, Li (2014), "A General Equilibrium Analysis of the TPP Free Trade Agreement With and Without China", The Journal of Applied Economic Research, May 2014 8: 115-136.

\section{APPENDIX A}

\begin{tabular}{|c|c|c|c|c|c|}
\hline SL & \begin{tabular}{|c|} 
Aggregate \\
$d$ \\
Region
\end{tabular} & GTAP Region & SL & $\begin{array}{l}\text { Aggregated } \\
\text { Commodities }\end{array}$ & GTAP Commodities \\
\hline 1 & China & China & 1 & $\begin{array}{l}\text { Grains Crops ( } 9 \\
\text { products) }\end{array}$ & $\begin{array}{l}\text { pdr wht gro } v_{f} f \text { osd } \\
\text { c_b pfb ocr pcr }\end{array}$ \\
\hline 2 & USA & $\begin{array}{l}\text { United States } \\
\text { of America }\end{array}$ & 2 & $\begin{array}{l}\text { Meat Lstk (6 } \\
\text { products) }\end{array}$ & $\begin{array}{l}\text { ctl oap rmk wol cmt } \\
\text { omt }\end{array}$ \\
\hline 3 & EU27 & $\begin{array}{l}\text { EU } 27 \\
\text { Countries }\end{array}$ & 3 & $\begin{array}{l}\text { Extraction ( } 6 \\
\text { products) }\end{array}$ & frs fsh coa oil gas omn \\
\hline 4 & Canada & Canada & 4 & $\begin{array}{l}\text { ProcFood ( } 5 \\
\text { products) }\end{array}$ & vol mil pcr sgr ofd \\
\hline 5 & Mexico & Mexico & 5 & Text Wapp (2) & tex wap \\
\hline 6 & AustNewz & $\begin{array}{l}\text { Australia and } \\
\text { New Zealand }\end{array}$ & 6 & LightMnfe (7) & $\begin{array}{l}\text { lea lum ppp fmp mvh } \\
\text { otn omf }\end{array}$ \\
\hline 7 & Japan & Japan & 7 & HeavyMnfc (7) & $\begin{array}{l}\text { p_ccrp nmmi_s nfm ele } \\
\text { ome }\end{array}$ \\
\hline 8 & Singapore & Singapore & 8 & Util_Cons (4) & ely gdt wtr cns \\
\hline 9 & Malaysia & Malaysia & 9 & Trans Comm (5) & trd otp wtp atp $\mathrm{cmn}$ \\
\hline 10 & Viet Nam & Viet Nam & 10 & Oth Services (6) & ofi isr obs ros og dwe \\
\hline 11 & Banglad esh & Bangladesh & & & \\
\hline 12 & India & India & & & \\
\hline 13 & Pakistan & Pakistan & & & \\
\hline 14 & Sri Lanka & Sri Lanka & & & \\
\hline 15 & Nepal & Nepal & & & \\
\hline 16 & SSA & $\begin{array}{l}\text { All Sub-Sahara } \\
\text { African }\end{array}$ & & & \\
\hline 17 & $\begin{array}{l}\text { Rest of the } \\
\text { world }\end{array}$ & $\begin{array}{l}\text { Rest of } \\
\text { countries in } \\
\text { the World of } \\
\text { GTAP } \\
\text { Datab ase }\end{array}$ & & & \\
\hline
\end{tabular}

